\title{
Editorial
}

\section{Balancing Mutual Trust and Fundamental Rights Protection in the Context of the European Arrest Warrant}

What Role for the Gravity of the Underlying Offence in CJEU Case Law?

\author{
Jannemieke Ouwerkerk \\ Institute of Criminal Law and Criminology, Leiden University, Po Box 9520, \\ 2300 RA Leiden, the Netherlands \\ j.w.ouwerkerk@law.leidenuniv.nl
}

Ever since the adoption of the Framework Decision on the European Arrest Warrant ${ }^{1}$ - the very first instrument that implemented the mutual recognition principle in the criminal law context - the relationship between the effectiveness of this instrument and the proper protection of fundamental rights have been widely and fiercely discussed. The stormy debates have calmed down a little since the Court of Justice of the EU (hereinafter: 'CJEU' or the 'Court') handed down its judgment in the joined cases of Aranyosi and Căldăraru; for the first time since the birth of the European Arrest Warrant (hereinafter: EAW) regime, the Court has accepted that in cases of a serious risk of inhumane treatment in the issuing Member State's prisons, surrender proceedings in the executing Member State must be suspended until sufficient supplementary information discounts that risk, and can eventually - i.e. where such

1 Framework Decision 2002/584/JHA of 13 June 2002 on the European arrest warrant and the surrender procedures between Member States [2002] OJ L19o/1.

(C) OUWERKERK, 2018 | DOI 10.1163/15718174-02602002

This is an open access article distributed under the terms of the prevailing CC-BY-NC License at the time of publication. 
supplementary information is not obtained within a reasonable time - be brought to an end. ${ }^{2}$

The Court's judgment in Aranyosi/Căldăraru has widely been interpreted as marking or, at least, confirming that the CJEU has started to follow a new avenue in EAW cases: the avenue of a restored balance between effective enforcement and adequate protection of fundamental rights. ${ }^{3}$ But what no one seems to have been wondering so far is whether the - comparatively speaking smallness of the criminal offences underlying the EAW's in those cases may also have worked out to the advantage of fundamental rights protection.

With particular attention for the gravity of the offences at hand, the following aims to describe and contrast two cases in which the Court was asked to decide on the scope of mutual trust in relation to fundamental rights concerns on the part of the issuing Member States. Two judgments have been selected: first, the abovementioned judgment in the joined cases of Aranyosi and Căldăraru, and secondly, the Court's judgment in the case of Lanigan on time-limits and the right to liberty. What these cases have in common is their primary focus on the functioning of mutual trust and mutual recognition in relation to core fundamental rights. In my view, this makes these cases different from other CJEU judgments that primarily deal with the interpretation of technical-legal terms laid down in the EAW Framework Decision, ${ }^{4}$ or that question the hierarchy

2 CJEU 5 April 2016, Joined Cases C-404/15 and C-659/15 PPU, proceedings relating to the execution of European arrest warrants issued in respect of Pál Aranyosi and Robert Căldăraru, ECLI:EU:C:2016:198.

3 See inter alia: L. Mancano, 'A New Hope? The Court of Justice Restores the Balance Between Fundamental Rights Protection and Enforcement Demands in the European Arrest Warrant System', in C. Brière and A. Weyembergh, eds., The Needed Balances in EU Criminal Law (Oxford and Portland, Oregon: Hart Publishing, 2018), pp. 285-312; T. Marguery, 'Rebuttal of Mutual Trust and Mutual Recognition in Criminal Matters: Is "Exceptional" Enough?, 1 European Papers (2016), pp. 943-963; S. Peers, 'Human Rights and the European Arrest Warrant: Has the turned from poacher to gamekeeper?', blog posted on EU Law Analaysis, 12 November 2016, available on: http://eulawanalysis.blogspot.nl/2016/11/human-rights-and-european-arrest .html (last accessed on March 6, 2018).

4 E.g.: CJEU 24 May 2016, Case C-108/16 PPU, proceedings relating to the execution of a European arrest warrant issued against Pawet Dworzecki, ECLI:EU:C:2016:346; CJEU 1 June 2016, Case $\mathrm{C}-241 / 15$, proceedings relating to the execution of a European arrest warrant issued against Niculaie Aurel Bob-Dogi, ECLI:EU:C:2016:385; CJEU 10 November 2016, Case C-477/16 PPU, proceedings relating to the execution of a European arrest warrant issued against Ruslanas Kovalkovas, ECLI:EU:C:2016:861; CJEU 10 November 2016, Case C-452/16 PPU, proceedings relating to the execution of a European arrest warrant issued against Krzystof Marek Poltorak, ECLI:EU:C:2016:858. 
between EU-level norms and national constitutional rights. ${ }^{5}$ True as it may be that the Court's decisions in these other cases have an impact on the scope of procedural rights and fundamental rights, and as such on the level of rights protection in EAW cases, these other judgments do not as such question the scope of mutual trust in cases where the issuing of an EAW (allegedly) violates core EU-level fundamental rights. This, however, has been the main question in the selected cases of Aranyosi/Căldăraru and Lanigan, which makes both cases eligible for comparison in the framework of this editorial.

In Aranyosi/Căldăraru, the Court has been found ready to accept an exemption from the obligation to swiftly recognise EAw's without assessing the protection of fundamental rights in the issuing Member State's criminal justice system. In these cases, the executing Member State (Germany) had to decide, first, on the surrender of an Hungarian national (Aranyosi) whose surrender was sought by Hungary in relation to the forced entry into a dwelling house from which he allegedly stole various objects of value as well as approximately EUR 2.813 in cash, and the entering by a window of a school in which he forced the opening of doors and from which he allegedly stole technical equipment and cash money with a total value of approximately EUR $930 .{ }^{6}$ The second EAW came from Romania and related to a Romanian national (Căldăraru) whose surrender was sought for the purpose of executing a final sentence of one year and eight months imprisonment, imposed for the offence of driving without a driving license. ${ }^{7}$ The German authorities wondered whether the poor detention conditions in both Hungary and Romania would constitute a ground for non-execution of the EAW's.

The Court explicitly held that evidence of deficiencies with respect to prison conditions in the issuing Member States requires the executing Member State to assess into detail the likelihood that the individuals concerned will be exposed to inhumane or degrading treatment after their surrender to the issuing Member States. ${ }^{8}$ The executing Member State's finding that there is a

5 E.g.: CJEU 26 February 2013, Case C-399/11, proceedings Stefano Melloni v. Ministerio Fiscal, ECLI:EU:C:2013:107.

6 CJEU 5 April 2016, Joined Cases C-404/15 and C-659/15 PPU, proceedings relating to the execution of European arrest warrants issued in respect of Pál Aranyosi and Robert Căldăraru, ECLI:EU:C:2016:198, paras. 28-31.

7 CJEU 5 April 2016, Joined Cases C-404/15 and C-659/15 PPU, proceedings relating to the execution of European arrest warrants issued in respect of Pál Aranyosi and Robert Căldăraru, ECLI:EU:C:2016:198, paras. 47-50.

8 CJEU 5 April 2016, Joined Cases C-404/15 and C-659/15 PPU, proceedings relating to the execution of European arrest warrants issued in respect of Pál Aranyosi and Robert Căldăraru, ECLI:EU:C:2016:198, paras. 88-92. 
real risk ('substantial grounds to believe') of such an inhumane and degrading treatment must result in a postponement of the surrender proceedings ('it cannot be abandoned'), until the issuing Member State on urgent request of the executing Member State has obtained all necessary supplementary information on the conditions the sought person is envisaged to be detained after surrender. ${ }^{9}$ It is true that the Court has remained rather vague on the precise consequences if the risk of inhumane and degrading treatment cannot be discounted within a reasonable time; it obviously tried to avoid using the terms 'refusal' and 'non-execution', and held that in such a case the executing Member State 'must decide whether the surrender procedure should be brought to an end.' ${ }^{10}$ But the fact remains - and this is a novelty - that the Court has explicitly accepted room for the executing Member State to carry out an intermediate check on the actual level of fundamental rights protection in the issuing Member State, thereby allowing for a rebuttal of mutual trust in the context of EAW proceedings.

Whilenotdenying the importance of the Court'srulingin Aranyosi/Căldăraru, I have been wondering whether the, comparatively speaking, smallness of the criminal offences that were underlying the Hungarian and Romanian EAw's may have impacted to some extent on the Court's decision to accept the possibility for rebuttal of the mutual trust principle - the very foundation of the mutual recognition model after all. Intuitively, one may be inclined to answer this question in the negative since on a principled level a core fundamental right, such as the right not be exposed to inhumane or degrading treatments in detention, must be safeguarded, irrespective of the criminal offence at hand. And indeed, I would not dare to suggest that the nature of the offences in the cases of Aranyosi and Căldăraru would have been a very explicit matter of significance in the Court's deliberations in these cases. But perhaps the question seems less strange, and less provocative, would it be turned around: would the Court have been ready to deliver this ruling if Aranyosi's prosecution would have been sought for several brutal murders, and if Căldăraru's prison sentence would have been imposed because he was found guilty of terrorist attacks? Moreover, how unlikely is it that the Court's choice for postponement instead of non-execution, at least on the short-term, relates to the possibility that future similar EAW cases may deal with much more serious offences?

9 CJEU 5 April 2016, Joined Cases C-404/15 and C-659/15 PPU, proceedings relating to the execution of European arrest warrants issued in respect of Pál Aranyosi and Robert Căldăraru, ECLI:EU:C:2016:198, para. 98.

10 CJEU 5 April 2016, Joined Cases C-404/15 and C-659/15 PPU, proceedings relating to the execution of European arrest warrants issued in respect of Pál Aranyosi and Robert Căldăraru, ECLI:EU:C:2016:198, para. 104. 
In my view, the issue becomes even less far-fetched if we compare the aforementioned ruling with the Court's ruling in the case of Lanigan. ${ }^{11}$ In this case, the Court had to deal with two questions, first whether non-compliance with the time-limits would exempt the executing Member State (in this case Ireland) from its obligation to adopt a decision on the issuing Member State's (United Kingdom) request for surrender; and, second, whether the expiry of time-limits should have consequences for the continuation of custody. ${ }^{12}$ At the time the High Court of Ireland referred its questions to the CJEU, almost two years had passed since the issuing of the EAW - whereas pursuant to Article 17 of the Framework Decision EAW a final decision is required within 90 days. ${ }^{13}$ During almost all that time, Lanigan, who was arrested one month after the receipt of the EAW, had been held in custody. ${ }^{14}$

The CJEU ruling in this case has been welcomed by some, in particular because of its decision on the second question: although the Court has held that exceeding the time-limits must not automatically result in the (provisional) release of the sought person, ${ }^{15}$ it explicitly stated that any decision taken on the sought person's custody or release while awaiting the final decision on surrender, must comply with the right to liberty as laid down in Article 6 of the EU Charter of Fundamental Rights. ${ }^{16}$ It has been argued that in its ruling in Lanigan - i.e. by its reference to the requirement of compliance with Article 6 of the EU Charter - the Court has for the first time expressly allowed a fundamental rights check in the executing Member State. ${ }^{17}$ But as to this issue, one can disagree on how novel the Lanigan judgment actually is. After all, would the Court really have been able to stipulate a lower level of protection regarding the right of liberty than it currently does? Of course not. Such a decision would boil down to rule out the applicability of the Strasbourg right to liberty-standards (included in Article 6 of the EU Charter) to keeping a person

11 CJEU 16 July 2015, Case 237/15 PPU, proceedings Minister for Justice and Equality v. Francis Lanigan, ECLI:EU:C:2015:474.

12 CJEU 16 July 2015, Case 237/15 PPU, proceedings Minister for Justice and Equality v. Francis Lanigan, ECLI:EU:C:2015:474, para. 20.

13 See Framework Decision 2002/584/JHA of 13 June 2002 on the European arrest warrant and the surrender procedures between Member States [2002] OJ L19o/1.

14 CJEU 16 July 2015, Case 237/15 PPU, proceedings Minister for Justice and Equality $v$. Francis Lanigan, ECLI:EU:C:2015:474, paras. 14-19.

15 CJEU 16 July 2015, Case 237/15 PPU, proceedings Minister for Justice and Equality v. Francis Lanigan, ECLI:EU:C:2015:474, paras. 45-46.

16 CJEU 16 July 2015, Case 237/15 PPU, proceedings Minister for Justice and Equality v. Francis Lanigan, ECLI:EU:C:2015:474, paras. 53-54.

17 See, e.g.: T. Marguery, 'Rebuttal of Mutual Trust and Mutual Recognition in Criminal Matters: Is “Exceptional" Enough?, 1 European Papers (2016), pp. 951-952. 
in custody pending a final decision on surrender. Such would not only have ran counter the binding character of the EU Charter, it would also have neglected the fact that it is on the territory of the executing Member State that the sought person is held in custody. After all, where the Lanigan judgment allowed the executing Member State to assess compliance with fundamental rights in the EAW context, this is limited to what all EU Member States were already bound to do, i.e. to ensure that the duration of the sought person's custody complies with the minimum rules provided for in Article 6 of the EU-Charter. No less, but certainly no more. Earlier I have argued that because of this, the Court's judgment in the case of Lanigan gives the impression that the efficient functioning of the mutual recognition principle precedes a generous safeguarding of the right to liberty - indeed one of the core fundamental rights. I wondered why the Court did not decide to formulate a principle of (conditional) release from custody if time-limits for a final decision on surrender are seriously exceeded, while leaving open the possibility that such a principle could be derogated from in circumstances that cannot allow a release of the sought individual. I have been thinking that perhaps the Court has felt unauthorised to design such a protective principle; because of its harmonising effect such a decision might have purposively left to the Eu legislature. ${ }^{18}$ But rethinking the CJEU judgments in both Lanigan and Aranyosi/Căldăraru, the question that keeps on spinning in my mind is a reversed one this time, namely whether the Court's reluctance to provide for a stronger protection of the fundamental right to liberty might - at least partly - relate to the fact that Lanigan's surrender was sought by the UK for his alleged involvement in two very serious crimes: murder and possession of a firearm with intent to endanger life. ${ }^{19}$

An answer to the aforementioned question cannot be given today. But I deem it important to raise the matter of the seriousness of the criminal offence in EAW cases and its potential impact on the scope granted by the CJEU to the executing Member State to assess compliance of serious infringing measures, imposed on individuals in the course of surrender proceedings and afterwards. Awareness of the potential impact of the gravity of the underlying offence might be necessary to avoid us from drawing general conclusions where that might be wrong, and, instead, to see things in their proper perspective.

Now one can argue - probably very convincingly - that in criminal matters the seriousness of the offence should not have an adverse effect on the

18 See my note on the Lanigan case: J.W. Ouwerkerk, Case Note on HvJ EU 16 July 2015, no. C-237/15, in European Human Rights Cases (2015/212) (in Dutch only).

19 CJEU 16 July 2015, Case 237/15 PPU, proceedings Minister for Justice and Equality v. Francis Lanigan, ECLI:EU:C:2015:474, paras. 14-16. 
required level of fundamental rights protection. Sympathetic as this position is, it provides no guarantee that in law enforcement and adjudicating practices the smallness of offences does work out to the advantage of fundamental rights protection, and vice versa. It remains to be seen how national courts will apply the CJEU's standards on fundamental rights checks in future EAW cases relating to criminal offences with a very different level of gravity than were the case in Aranyosi/Căldăraru and in Lanigan. Moreover, it has to be awaited how the Court's strand of EAW case-law will develop, before careful conclusions can be drawn on whether and how the seriousness of the offence plays a role in cross-border fundamental rights protection. But in my view the judgments in Aranyosi/Căldăraru and Lanigan already give rise to involve also the nature of the criminal offence at stake in our future analyses of CJEU case-law in the criminal law domain. 